\title{
The Property of Lime Sewage Sludge and its Influence on Co-Processing in Cement Kilns
}

\author{
Haihua Cao, Jia Liu, Jingcheng Xu*, Wei Liu, \\ Xiangfeng Huang, Guangming Li \\ College of Environmental Science and Engineering, Tongji University, Shanghai 200092, China, \\ Key Laboratory of Yangtze River Water Environment of Education Ministry, Shanghai 200092, China
}

Received: 5 March 2015

Accepted: 16 February 2016

\begin{abstract}
In recent years, co-processing lime-dried sludge (LS) in cement kilns has attracted increasing interest in China. However, there are few published studies focused on the effect of sludge properties. In this study, LS properties and their effects on co-processing in a cement kiln were studied by performing experimental analyses and theoretical calculations. The results indicated that the heating value of municipal sewage sludge (MSS) was decreased with lime dosage. By adding $10 \%$ lime, the heating value would be almost halved to $7,198 \mathrm{~kJ} / \mathrm{kg}$. Heavy metals in LS are much lower than the limit concentration of the standard. Chlorine and sulfur are about $0.06-0.35 \%$ and $0.22-0.56 \%$, respectively, which completely meets the relation requirement. Additionally, adding lime promotes the transformation and decomposition of ammonia and protonated amine proteins, nitrogen, and the generation of pyridine nitrogen. Theoretical calculation results show that the maximum co-processing ratio for $\mathrm{RS}$ is $4.5 \%$, which can be increased by increasing the addition of a suitable amount of lime $(0-16 \%) .10 \%$ with a $6.5 \%$ maximum co-processing ratio is suggested as the optimum lime dosage for co-combustion of LS in cement kilns.
\end{abstract}

Keywords: lime-dried sludge, sludge properties, cement kiln, lime dosage, co-processing

\section{Introduction}

Domestic wastewater capacity in China has maintained a rapid growth trend in recent years, and has reached 125 million $\mathrm{m}^{3} / \mathrm{d}$ in 2013 [1]. As the by-product of wastewater treatment, the weight of municipal sewage sludge (MSS) has significantly increased. At present,

*e-mail: xujick@tongji.edu.cn jcxutj@126.com
MSS production is about 6 million tons (measured as dry matter) [2], and this total is predicted to reach 12 million tons [3]. As such, the treatment of sludge is of increasing importance in China.

Dewatering sludge is well known as one of the most difficult and important processes in effective MSS treatment and resource utilization. In China, the longstanding and most frequently used dewatering methods are centrifuges, belt pressures, and filter presses. However, in recent years a lime-drying process has been widely adopted in wastewater treatment plants (WWTPs) in 
China. These include the Xiaohongmen and Fangzhuang WWTPs in Beijing, the Jizhuangzi WWTP in Tianjing, and the Jiading WWTP in Shanghai [4-6]. In addition to the lime being used to improve dewatering performances (frequently about $7 \%$ weight percentage), numerous other lime concentrations are being used to achieve better dewatering results with a lime-drying process. A $20 \%$ lime dosage by weight has been reported as being necessary to reduce sludge moisture from $80.62 \%$ to $60 \%$ [7]. Then there is a challenge in the subsequent disposal of lime-dried sludge (LS). Landfilling, incineration, agricultural use, and composting have been China's most frequently used sludge disposal methods [8], with landfilling being the most widely used. However, the problems of odor and landfill leachates have resulted in the adoption of increasingly strict standards [9]. As an alternative, incineration has attracted increasing attention. Sludge incineration technologies can be grouped into two categories: mono-incineration and co-combustion technologies [10]. Due to its lower energy consumption and greenhouse gas emissions, the latter has been growing in popularity in China [11]. As reported in our study, cocombustion of sludge in cement kilns has been gradually adopted in cities such as Beijing, Guangzhou, and Hangzhou. In addition, LS co-processing projects have also been reported $[11,12]$.

Due to LS co-processing programs still in the initial stage, there are few reports specific to this technology. Fortunately, a few developed countries such as the United States and Japan, as well as a number of countries in the European Union, have more experience with coprocessing wastes or raw sludge (RS) in cement kilns [13]. A number of common factors have been identified and should be examined. In particular, consideration should be given to the properties of sludge and its overall suitability for co-processing.

Firstly, the moisture content of sludge can affect its stability and convenience in transport, and its storage and kiln-feeding operations. Furthermore, high moisture content may cause a temperature drop and an increase in the evaporated water in cement kilns, which can cause a reduction in product quality and potential overload for the off-gas cleaning devices. A moisture content of less than $30 \%$ has been suggested [13-15]. Secondly, heating value is a decisive parameter in determining the amounts of conventional fuel required in substitutions [14, 16, 17]. It is also inextricably connected with the organic matter and moisture contents. The cement industry requires a heating value of greater than $6,250 \mathrm{~kJ} / \mathrm{kg}$ [16]. Lastly, it is well known that the ash produced in the sludge combustion process is absorbed by the cement clinker product. Since the chemical composition of the sludge may vary $(\mathrm{CaO}$, $\mathrm{SiO}_{2}, \mathrm{Al}_{2} \mathrm{O}_{3}, \mathrm{Fe}_{2} \mathrm{O}_{3}$ ), they may affect cement quality. If the weight percentage of sludge ash is greater than $50 \%$ and the volume of raw material in sludge ash is greater than $80 \%$, it can be used as a good alternative material [13-15]. Overall, it cannot be overemphasized that sludge properties have significant effects on co-combustion of sludge in a cement kiln.
In contrast to the sludge produced in developed countries, sludge in China has less organic matter (30$50 \%$ compared with $60-70 \%$ in developed countries) and higher sand content, due to inefficient wastewater treatment systems and the different lifestyles of its residents [18, 19]. Moreover, after the addition of lime, sludge properties differ with respect to their heating values, chemical compositions, and organic forms. Naturally, these differences affect sludge co-processing, i.e., disposal capacity and gas pollutant emissions. Hence, it is important to study lime sludge properties and its influence on co-processing in cement kilns as this technology is being widely adopted.

This study used the gravimetric method to determine the moisture content and organic matter present in the sludge. The water-solid bond strength was also studied by combining thermal gravimetry analysis (TGA) and differential thermal analysis (DTA) [20]. In addition, chemical composition and heating value of sludge were also investigated, as well as the changes in its organic forms. Lastly, this article calculated the theoretical coprocessing capacity and the material flow for co-processing LS in cement kilns based on the sludge properties' results.

\section{Materials and Methods}

\author{
Sludge Sample \\ and Experimental Procedures
}

An RS sample was collected from a municipal WWTP in Beijing that employed an anaerobic/anoxic/oxic process to remove nitrogen and phosphorus from the wastewater. Its physicochemical characteristics and elemental analysis were shown in Table 1.

The major experimental procedures were as follows: adding $\mathrm{CaO}$ (particle diameter $<100$ mesh) to the sludge at $5 \%$ (sample LS5), $10 \%$ (LS10), $15 \%$ (LS15), or $20 \%$ (LS20) of the mass of the RS; mixing rapidly for $5 \mathrm{~min}$ and spreading on trays to dry in natural environment; and sampling sludge properties at $30 \mathrm{~min}, 0.5 \mathrm{~d}, 1 \mathrm{~d}, 3$ d, $7 \mathrm{~d}, 14 \mathrm{~d}$, and $21 \mathrm{~d}$. Besides, some theoretical analysis and calculations were done to study the effect of sludge properties on co-processing.

Table 1. Physicochemical characteristics and elemental analysis of the dewatered sludge.

\begin{tabular}{|c|c|c|c|c|c|c|}
\hline \multirow{2}{*}{ Item } & \multicolumn{3}{|c|}{ Proximate analysis ${ }^{\text {a }}$} & \multicolumn{3}{c|}{ Ultimate analysis } \\
\cline { 2 - 7 } & Moisture & $\begin{array}{c}\text { Volatile } \\
\text { matter }\end{array}$ & Ash & $\mathrm{C}$ & $\mathrm{H}$ & $\mathrm{N}$ \\
\hline $\begin{array}{c}\text { Value } \\
(\mathrm{wt} \%)\end{array}$ & 86.6 & 60.4 & 35.8 & 37.06 & 5.38 & 5.07 \\
\hline
\end{tabular}

a The values of ash, volatile matter, $\mathrm{C}, \mathrm{H}, \mathrm{N}$ were in dry mass. 


\section{Samples Analysis}

\section{Moisture Content}

According to the standard of Determination Method for Municipal Sludge in Wastewater Treatment Plant (CJ/T 221-2005)[21], the gravimetric method was used to determine the moisture content in each sludge sample, as calculated by Eq. (1):

$$
\omega_{1}(\%)=\frac{\left(\mathrm{w}_{1}-\mathrm{w}_{2}\right)}{\mathrm{w}_{1}} \times 100
$$

... where $\mathrm{w}_{1}$ is the mass of the sludge sample (approximately $10 \mathrm{~g}$ ) and $\mathrm{w}_{2}$ is the mass after drying in an electric oven at $103-105^{\circ} \mathrm{C}$ for $2 \mathrm{~h}$.

\section{Volatile Matter and Ash}

The gravimetric method was used to determine the release of volatiles from the sludge samples using Eq. (2).

$$
\omega_{2}(\%)=\frac{\left(\mathrm{w}_{2}-\mathrm{w}_{3}\right)}{\mathrm{w}_{2}} \times 100
$$

...where $\mathrm{w}_{3}$ is the mass of the sludge sample after two continued prepayment steps: first the sludge was dried in an electric oven for $2 \mathrm{~h}$ at $103-105^{\circ} \mathrm{C}$ and then it was incinerated in a muffle furnace at $550 \pm 50^{\circ} \mathrm{C}$ for $1 \mathrm{~h}$. Eq. (3).

The quantity of ash in the sample was calculated using

$$
\omega_{3}(\%)=1-\omega_{2}(\%)
$$

\section{Elemental Analysis}

Samples were vacuum freeze-dried (Scientz-10N) for $24 \mathrm{~h}$ at $65 \mathrm{~Pa}$ with a cold trap temperature of $-50^{\circ} \mathrm{C}$ and material temperature of $-25^{\circ} \mathrm{C}$. Before elemental analysis, the dry samples were ground to powders ( $<200 \mathrm{mesh})$, and then the $\mathrm{C}, \mathrm{H}$, and $\mathrm{N}$ contents were determined using a Vario EL III elemental analyzer (Germany).

\section{Water-Solid Bond Strength}

Using the method recommended by Chen [20], the continuous moisture distribution in waste-activated sludge was calculated by combining TGA and DTA (Q600 SDT).

\section{Chemical Composition}

The chemical composition of the sludge samples and raw meal were confirmed using a wavelength dispersion $\mathrm{X}$-ray fluorescence spectrometer (XRF) (PW2404), and pretreatment of vacuum freeze-dried also needed as previous.

\section{Heavy Metal}

Heavy metal concentration: The heavy metal concentrations in the samples were confirmed by inductively coupled plasma atomic emission spectroscopy (ICP-AES) (Agilent720ES). The samples were crushed and the heavy metals were extracted by acid (HF: $\mathrm{HClO}_{4}: \mathrm{HNO}_{3}=2: 1: 1$ ) in a closed microwave digestion instrument (Milestone ETHOS1).

\section{Heating Value}

The dry matter heating value in freeze-dried sludge samples were determined using an oxygen bomb calorimeter (IKAC5000). Moreover, the higher heating value (HHV) and lower heating value (LHV) of the samples were calculated using Eqs. (4-5), respectively:

$$
\mathrm{HHV}=\left(1-\omega_{1}(\%)\right) \times \text { dry matter heating value }
$$

$\mathrm{LHV}=\mathrm{HHV}-\left(\omega_{1}(\%) \times \mathrm{c} \times(373-\mathrm{T})+\omega_{1}(\%) \times \mathrm{H}_{\mathrm{v}}\right)$

... where $\mathrm{c}$ is the specific heat of water $(4.2 \mathrm{~kJ} / \mathrm{kg}), \mathrm{T}$ is room temperature $(298 \mathrm{~K})$, and $\mathrm{H}_{\mathrm{v}}$ is the evaporation heat of water $(2,260 \mathrm{KJ} / \mathrm{Kg})$.

\section{Fourier Transform Infrared Spectroscopy (FTIR)}

The FTIR spectra of the sludge samples were obtained using an FTIR spectrophotometer (Nicolet 5700). Before analysis the wet samples were freeze-dried. Each lyophilized sample was placed on a gold mirror and analyzed using reflection mode in the wave number range $400-4,000 \mathrm{~cm}^{-1}$.

\section{X-ray Photoelectron Spectroscopy (XPS)}

Nitrogen speciation of the freeze-dried samples was investigated by XPS with an Axis Ultra DLD (Kratos Analytical). A monochromatic $\mathrm{Al} \mathrm{K} \alpha \mathrm{X}$-ray source $(1,486.6 \mathrm{eV})$ was used. In addition, the software package XPS peak 4.1 was used to fit the XPS peaks.

\section{Results}

\section{Effect of Lime on Sludge Moisture Content and Water-Solid Bond Strength}

Moisture content is very important for a sludge coprocessing system. On one hand, moisture content of sludge could decide the sludge-adding pattern. Sludge with high moisture content (close to liquid) should use a special pump, while low-moisture-content sludge (close to solid) is usually best on a chain plate conveyor. On the other hand, high moisture content may affect the heat balance in a cement kiln [22]. Sludge with high moisture 

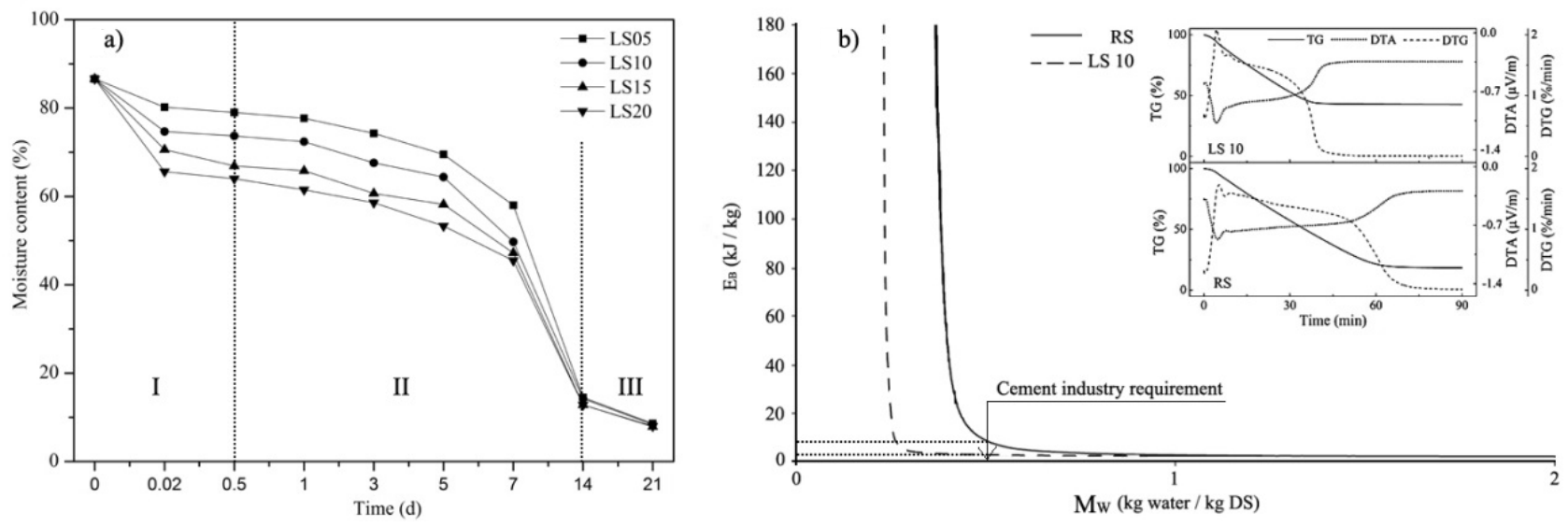

Fig. 1. Effect of lime on sludge moisture content and water-solid bond strength: a) moisture content decreased with time for different lime dosages in LS; b) bond strength versus residue moisture plot for RS and LS10.

content would consume a large amount of energy to water evaporating, and the sludge with lower moisture content could save part of the fuel. As such, moisture content is one of the limiting parameters during co-processing in a cement kiln. Unlike RS, the moisture content of LS has a noticeable relationship with the lime dosage and drying time. Moisture contents in different LS samples were monitored and the water-solid bond strengths of RS and LS10 also were compared, as shown in Fig. 1.

As shown in Fig. 1a, the sludge lime drying process could be separated into three stages: (I) hydration of quicklime, (II) natural air drying, and (III) stabilization. In the first stage, the addition of $\mathrm{CaO}$ rapidly increased the ratio of dry matter in sludge samples and its hydration exothermic reaction created a high temperature condition to evaporate the water in the sludge. As a result, the moisture content significantly decreased, and this decrease was positively correlated with lime dosage. Normally, this stage occurred in the mixer, where lime was vigorously mixed with rotary blades. Then the well-mixed sludge was spread out in WWTP to dry naturally, namely by entering the second stage of the drying process. The moisture content continuously decreased at this stage, with an accelerated decrease after three days of drying. At this point, almost all the interstitial water had been removed, leaving the sludge particles exposed to the air. Therefore, specific surface area of sludge samples increased and the water in the sludge evaporated quickly. This evaporation continuously affected the moisture content in stage II. In addition, it was noted that the moisture content could drop below $60 \%$ when adding sufficient lime (dosage $>10 \%$ ) and drying for seven days. During the stabilization stage, LS was naturally dried for 14 days. The moisture contents for all experimental conditions were below 20\% (mainly comprising surface water and bound water). Thus, a high dewatering efficiency was achieved.

The relationship between water-solid bond strength and residue moisture in the combined TGA and DTA [20] and the results are illustrated in Fig. 1b. Notably, when the residue moisture content was high (greater than $1 \mathrm{~kg}$ water $\cdot \mathrm{kg} \mathrm{DS}^{-1}$ ), the bond strength was essentially zero. This high-moisture content exhibited almost the same energy level as bulk water, which meant it was free water in the sludge. However, when the residue moisture content was less than $1 \mathrm{~kg}$ water $\mathrm{kg} \mathrm{DS}^{-1}$, the bond strength significantly increased, and continued to increase as the residue moisture content continued to decrease. After adding lime, the bond strength was significantly reduced. As shown in Fig. 1b, when Mw was $0.53 \mathrm{~kg}$ water $\cdot \mathrm{kg}$ $\mathrm{DS}^{-1}$ (35\% moisture content), LS had a much weaker bond strength than RS. Therefore, the addition of lime can improve the dewatering efficiency. This is because the lime hydration reaction uses not only the interstitial water but also some portion of the surface water and bound water.

In short, the lower moisture content and weaker watersolid bond strength in LS may have an active effect on the heating balance of cement kilns and the thermal drying process during co-combustion.

\section{Effect of Lime on Inorganic Composition}

\section{Effect of Lime on Chemical Composition}

The chemical composition of the raw material plays an important role while co processing sludge in a cement kiln. During cement production, these compositions are strictly controlled to a certain range. If the composition of sludge is similar to raw meal cement particles, it could be used as an alternative material in large amounts. If not, then limestone, clay, and ferrous raw materials should be added to guarantee a suitable composition, which means that the sludge should be added from raw mill, and be heated in a cyclone preheater and precalciner before entering the cement kiln. If raw mill is chosen to be the MSS feed point, some problems arise that will affect cement production, such as odorous matter emissions, bag filter overload, dioxin risk, and energy waste. Therefore, a careful investigation of the effect of lime on the composition of sludge is essential with respect to co-processing LS in 
Table 2. Chemical compositions of cement raw materials and sludge samples (wt \%).

\begin{tabular}{|c|c|c|c|c|c|c|c|}
\hline Samples & $\mathrm{LOI}^{\mathrm{a}}$ & $\mathrm{SiO}_{2}$ & $\mathrm{Al}_{2} \mathrm{O}_{3}$ & $\mathrm{Fe}_{2} \mathrm{O}_{3}$ & $\mathrm{CaO}$ & $\mathrm{MgO}$ & $\mathrm{P}_{2} \mathrm{O}_{5}$ \\
\hline $\mathrm{RS}$ & 65.26 & 6.09 & 3.22 & 5.74 & 6.09 & 0.98 & 6.02 \\
\hline LS5 & 55.03 & 4.05 & 1.65 & 2.54 & 41.05 & 1.49 & 2.88 \\
\hline $\mathrm{LS} 10$ & 48.80 & 2.08 & 1.43 & 2.26 & 61.75 & 1.09 & 2.09 \\
\hline LS15 & 42.84 & 1.85 & 1.29 & 1.60 & 75.15 & 0.93 & 1.89 \\
\hline LS20 & 35.58 & 1.90 & 1.28 & 1.40 & 88.72 & 1.10 & 1.69 \\
\hline
\end{tabular}

${ }^{a} \mathrm{LOI}$ : Loss on ignition at $1,000^{\circ} \mathrm{C}$.

cement kilns. XRF was used to determine the chemical compositions of different sludge samples, and the results are shown in Table 2.

From the data in Table 2 it can be found that RS has a high sand content. This may be explained by the low efficiency of the rotational flow grit chamber and incomplete wastewater treatment system processes. Moreover, high ferric salt and phosphorus contents are characteristic of RS. This is because chemical phosphorus removal techniques have been widely applied in WWTPs in recent years in China. Phosphorus can be removed from waste water by forming an iron phosphate precipitate, which may have caused phosphorus enrichment in the excess sludge. In addition, $\mathrm{CaO}$ is widely used as an amendment during the mechanical dewatering of sludge; hence, there is also a high $\mathrm{CaO}$ content in RS. In general, due to its similar composition with cement material, RS can be used as an alternative material in cement manufacturing [16].

The composition of LS samples is significantly different than that of RS. The weight percentage of $\mathrm{CaO}$ increases with the lime dosage, while other components significantly decrease - as is clearly shown in Fig. 2, which depicts the composition of RS as being similar to ferrous raw material, but different from that of raw meal. This means that other materials should be supplemented to guarantee a suitable composition when using RS to produce cement clinker. The addition of lime greatly changed the $\mathrm{CaO}-\mathrm{SiO}_{2}-\mathrm{R}_{2} \mathrm{O}_{3}$. In Fig. 2 we see that chemical composition of LS became more similar to raw meal with the increasing lime dosage. In addition, the main replacement for the raw material $(\mathrm{CaO})$ from $\mathrm{LS}$ was $\mathrm{Ca}(\mathrm{OH})_{2}$, because its decomposition energy $(57.86 \mathrm{~kJ} / \mathrm{mol})$ was far less than that of $\mathrm{CaCO}_{3}(178.50 \mathrm{~kJ} / \mathrm{mol})$ in raw materials. Consequently, this helped conserve the energy required for $\mathrm{CaCO}_{3}$ decomposition [23].

\section{Effect of Lime on Heavy Metal}

To ensure clinker quality and reduce pollution emissions, the heavy metal of cement raw material must be monitored and controlled during cement production. For co-processing LS in a cement kiln, heavy metals in sludge as well as mixed raw materials were detected

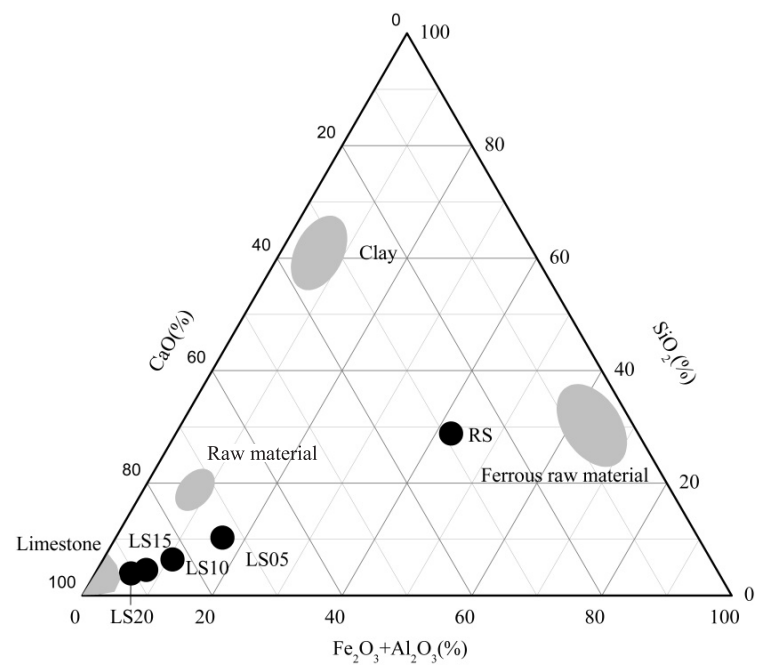

Fig. 2. Chemical composition of ash from sludge samples, clay, raw material, limestone, and ferrous materials in a ternary diagram of $\mathrm{CaO}-\mathrm{SiO}_{2}-\mathrm{R}_{2} \mathrm{O}_{3}$.

in this work. The results of heavy metal concentrations are shown in Table 3. As shown in Table 3, the heavy metal concentrations were on a low level, which ranged between $1 \mathrm{mg} / \mathrm{kg}$ to $130 \mathrm{mg} / \mathrm{kg}$, except for $\mathrm{Zn}$. That's mainly because the sludge was collected from a domestic sewage treatment plant with fewer sources of heavy metal. In addition, heavy metal concentration decreased with the increasing lime dosage. For LS10, the heavy metal could be decreased to only half of RS, which could greatly reduce the risk. It is worth noting that all samples and all kinds of heavy metal were much lower than the requirement $(\mathrm{Cd}<45 \mathrm{mg} / \mathrm{kg}, \mathrm{Cr}<1,500 \mathrm{mg} / \mathrm{kg}, \mathrm{Pb}<1,500$ $\mathrm{mg} / \mathrm{kg}$, and $\mathrm{Zn}<10,000 \mathrm{mg} / \mathrm{kg}$ ) of "Code for design of sludge co-processing in cement kiln" (GB 50757-2010) [24], indicating that LS was suitable for co-processing in a cement kiln in the aspect of heavy metal.

\section{Effect of Lime on Chlorine and Sulfur}

According to the report published by Berkeley Lab [25], chlorine can cause accelerated corrosion of the facility and affect the overall quality of cement and concrete. The concentrations should not be greater than $0.7 \%$. Besides,

Table 3. Heavy metal concentrations of different lime-dried sludge $(\mathrm{mg} / \mathrm{kg})$.

\begin{tabular}{|c|c|c|c|c|c|c|c|}
\hline $\begin{array}{c}\text { Sam- } \\
\text { ples }\end{array}$ & As & $\mathrm{Cd}$ & $\mathrm{Cr}$ & $\mathrm{Cu}$ & $\mathrm{Ni}$ & $\mathrm{Pb}$ & $\mathrm{Zn}$ \\
\hline RS & 26.39 & 1.07 & 86.65 & 125.37 & 28.69 & 30.15 & 717.17 \\
\hline LS05 & 13.79 & 0.70 & 31.86 & 70.27 & 11.14 & 17.36 & 700.56 \\
\hline LS10 & 11.64 & 0.56 & 28.56 & 61.91 & 10.46 & 18.20 & 354.86 \\
\hline LS15 & 10.52 & 0.55 & 23.58 & 53.56 & 8.93 & 15.63 & 384.45 \\
\hline LS20 & 8.45 & 0.48 & 20.97 & 46.54 & 7.50 & 15.08 & 315.50 \\
\hline
\end{tabular}


Table 4. The effect of lime on chlorine and sulfur (wt \%).

\begin{tabular}{|c|c|c|c|c|c|}
\hline Samples & RS & LS05 & LS10 & LS15 & LS20 \\
\hline $\mathrm{Cl}$ & 0.35 & 0.29 & 0.11 & 0.06 & ND \\
\hline $\mathrm{S}$ & 0.56 & 0.48 & 0.34 & 0.23 & 0.22 \\
\hline
\end{tabular}

high concentrations of sulfur may lead to crusting at the cyclone preheater and calciner. Its concentration should be limited, and the common portland cement standard (GB/T 175-2007) [26] requires that sulfur be lower than $3.5 \%$.

The contents of chlorine and sulfur were detected by X-ray fluorescence (PW2404) and a Vario EL III elemental analyzer, respectively. The results are shown in Table 4. Chlorine of all LS samples was lower than $0.3 \%$, which completely meets the requirement. Sulfur concentration of RS was $0.56 \%$, which was much lower than the requirement. What's more, the concentration decreased with the increase of lime. Thus, low chlorine and sulfur of lime-dried sewage sludge should have little effect on co-processing.

\section{Effect of Lime on Organic Matter and Heating Value}

For co-combustion of sludge in cement kilns, sludge from WWTPs must be pretreated to reduce the water content. Using waste heat from cement kilns has been recommended to dry the sludge [22]. Furthermore, organic matter can help significantly control pollution odor during the thermal drying process. The heating value, which impacts the heat balance in cement kilns, has a close relationship with organic matter. Hence, the effect of lime on both organic matter and heating value is an important consideration in co-processing.

Fig. 3a shows the regulation of change for organic matter during the stabilization process. As seen in Fig. 3a, organic matter greatly decreases in stage I, while it remains almost unchanged in stages II and III. There are two reasons for the drop during stage I. The first is that the addition of lime increasing the solid content, hence the ratio of organic matter naturally decreases. The second reason is that the hydration reaction created a high-temperature and highly alkaline environment, which may have promoted the volatility and transformation of the organic matter, thus reducing its weight ratio. The increased solids content by the addition of lime is the main reason; its effect on the weight percentage of the organic matter was double that caused by the hydration reaction. However, during stages II and III, the loss of hydrolysis heat over time and the volatility of the organic matter ended, and the growth of the microorganism was prevented due to the highly alkaline environment [27]. Thus, the organic matter content was stable.

In this study, heating value of the sludge samples were also measured, as it was a key parameter in co-processing and was positively correlated with organic matter. As shown in Fig. 3b, the dry matter heating value of RS was $15908 \mathrm{~kJ} / \mathrm{kg}$, which was slightly higher than the Chinese average value $11,850 \mathrm{~kJ} / \mathrm{kg}$ [28], and roughly equal to that of inferior coal $(<18,800 \mathrm{~kJ} / \mathrm{kg})$. From Fig. 3b, it can be seen that the organic matter and heating value of dry matter decreases as the lime dosage increases. More importantly, the heating value of the dry matter showed a linear correlation with the organic matter. It is well known that LHV, considering the evaporation heat of water, can directly reflect the effect of the heating value on the heat balance in cement kilns. Hence, LHV of the sludge samples was calculated based on their moisture content and dry-matter heating values. The results showed that LHV of RS was $-98.2 \mathrm{~J} / \mathrm{kg}$, indicating that these conditions were not only unprofitable but also detrimental to the heating balance in the cement kilns. However, the use of lime drying can avoid this negative effect. For example, LHV and HHV of LS10 after drying for seven days were $2,585 \mathrm{~kJ} / \mathrm{kg}$ and $7,198 \mathrm{~kJ} / \mathrm{kg}$, respectively. Co-combustion of LS10 in cement kiln would not impact the heat balance.
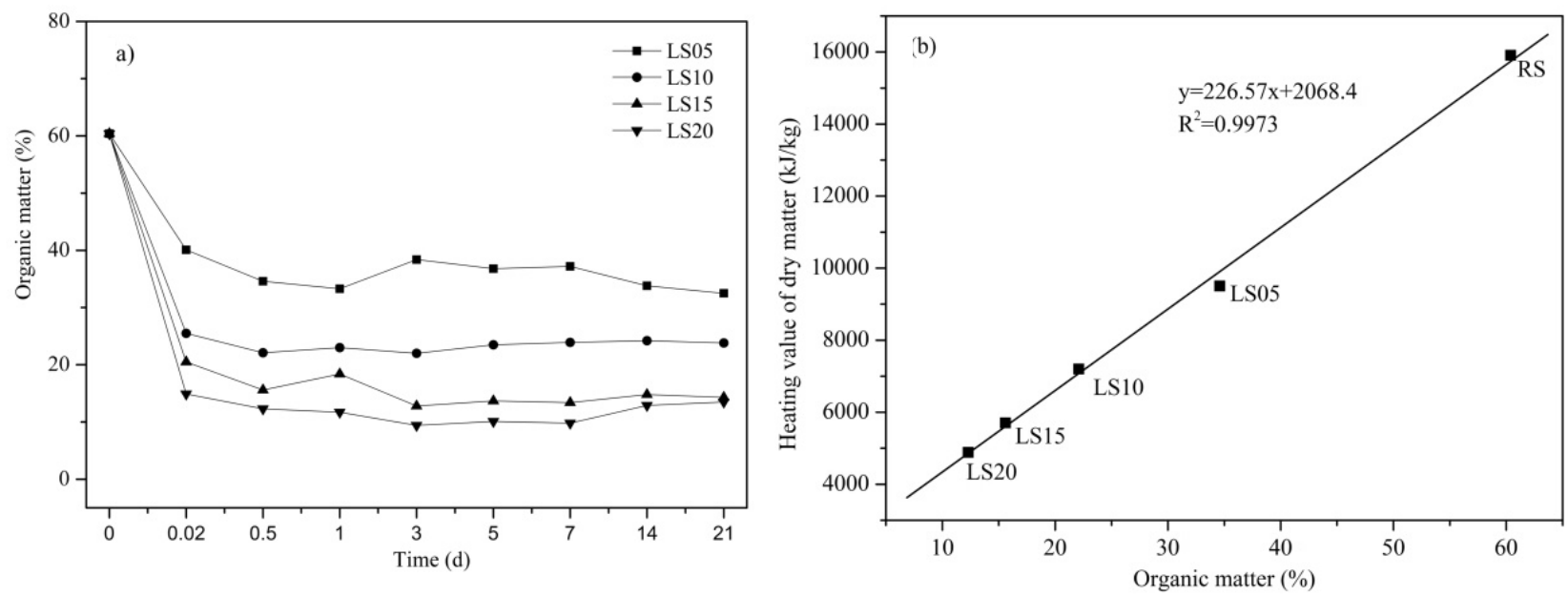

Fig. 3. Effect of lime on organic matter and the heating value: a) regulation of the change in organic matter content for different LS samples; b) relationship between the organic matter content and heating value of dry matter. 
However, it is worth noting that the heating value of sewage sludge should be at least $11,000 \mathrm{~kJ} / \mathrm{kg}$ or more for European cement factories (some cement industry requirements are 13,000 or $15,000 \mathrm{~kJ} / \mathrm{kg}$ ). Compared with the European standard, heating value requirement of the cement industry in China is relatively low. The reason is that the sludge of China has less organic matter (30-50\% compared with $60-70 \%$ in European) and cannot reach the heating value requirement of using sludge as conventional fuel for European cement factories. Thus, LS could be more appropriately used as cement raw material owing to its large amount of active compositions such as $\mathrm{CaO}$, $\mathrm{SiO}_{2}, \mathrm{Al}_{2} \mathrm{O}_{3}$, and $\mathrm{Fe}_{2} \mathrm{O}_{3}$.

\section{Effect of Lime on Organic Matter Form}

Because of the noticeable relationship between the form of the organic matter in sludge and the emission of gas pollutants during co-processing, XPS and FTIR to study the organic forms in both RS and LS samples. Figs 4 and 5 show the results of the FTIR and XPS spectra (using RS and LS10 as examples), respectively. In addition, the relative content of different functional groups was identified based on the XPS fitting results by XPS peak 4.1.

FTIR spectra of the sludge samples using previously published data [29, 30]. From Fig. 4 it can be seen that RS contained various organic species, including alkyl compounds, oxyacid hydroxyl acid and its derivatives, ketone, alcohol, and phenol. The lime-stabilized sludge, however, showed four obvious differences. The first was a sharp and strong band at $3,643 \mathrm{~cm}^{-1}$, which was attributed to the $\mathrm{O}-\mathrm{H}$ stretch vibrations of $\mathrm{Ca}(\mathrm{OH})_{2}-$ the hydration products of $\mathrm{CaO}$. The second difference was the absorbance at $874 \mathrm{~cm}^{-1}$, which became stronger with increases in the lime dosage. And this band to $\mathrm{CO}_{3}{ }^{2-}$ in $\mathrm{CaCO}_{3}$, which had been generated by the reaction . The third difference occurred between $1,550 \mathrm{~cm}^{-1}$ and

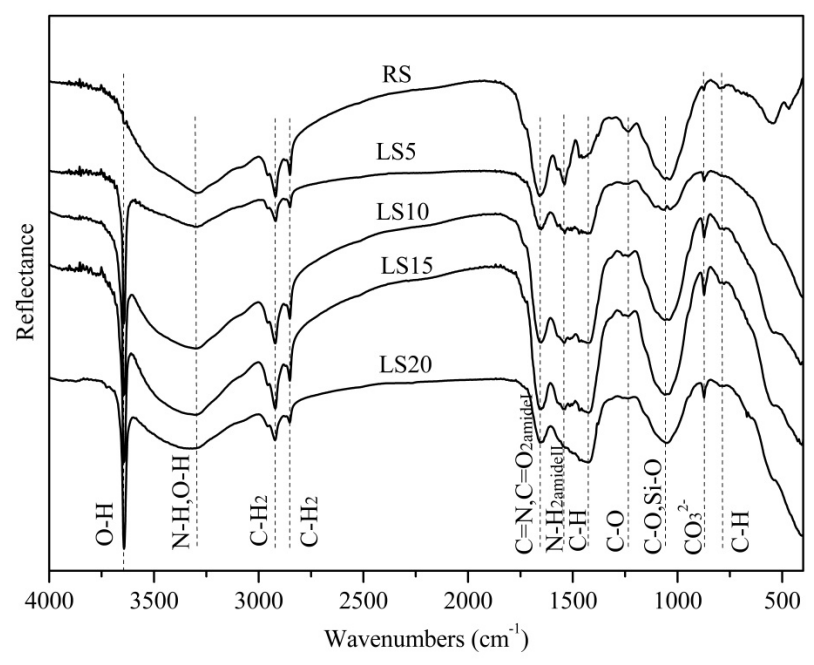

Fig. 4. FTIR spectra of different lime-conditioned sludge samples after being stabilized for $12 \mathrm{~h}$.
$1,300 \mathrm{~cm}^{-1}$. The strong bands around $1,540 \mathrm{~cm}^{-1}$ (amide II band) and $1,455 \mathrm{~cm}^{-1}$ (aliphatic $\mathrm{C}-\mathrm{H}$ stretching and bending) overlapped and became a broad absorption band as lime dosage increased. This was mainly caused by the hydrolysis of protein, which involves the breaking of the complex protein chains, resulting in a decrease of - $\mathrm{CO}-$ $\mathrm{NH}_{2}$ compounds [31]; hence, the weight ratio of the alkane compounds was naturally high. Lastly, the absorbance at $800-700 \mathrm{~cm}^{-1}$ became weaker due to the transformation and decomposition of aromatic compounds. The weight decrease of aromatic compounds was active to pollution control during the sludge drying process for co-processing in a cement kiln.

As previously mentioned, XPS was used to analyze the relative content of the different functional groups, and these results are shown in Fig. 5 and Table 5.

As shown in Fig. 5 and Table 5, C-C and $\mathrm{C}-\mathrm{H}$ were the predominant carbon chemical bonds for $\mathrm{RS}$, and account for the $70 \%$ peak area ratio at the $\mathrm{C} 1 \mathrm{~s}$ peak. Therefore, it could be identified that the primary carbonic compounds in sludge samples were aliphatic compounds. These findings were also in accord with the FTIR results. In addition, the addition of lime resulted in a marked increase in the relative contents of the $\mathrm{C}=\mathrm{O}$ and $\mathrm{O}-\mathrm{C}-\mathrm{O}$ compounds. This may be explained by the fact that the nucleophilic addition and dehydration reaction occurred under high-pH and high-temperature conditions.

From the $\mathrm{O} 1 \mathrm{~s}$ peak, it could be seen that there were few oxides in RS samples. In other words, oxygen in RS mainly existed in the form of organic O. Note that $\mathrm{COOH}$ in RS occupied about $20 \%$ of the peak area. In addition, according to the binding energy changes at 530.7 $\mathrm{eV}$ and $533.5 \mathrm{eV}$, the addition of lime not only increased the $\mathrm{O}$ in the $\mathrm{Ca}(\mathrm{OH})_{2}$ but also transformed the $\mathrm{O}$ in the $\mathrm{COOH}$ to inorganic oxides. Moreover, the $\mathrm{O}$ in the $\mathrm{O}-\mathrm{H}$ group decreased after the addition of lime, perhaps due to the conversion and decomposition of the alcohols and phenols.

In this study, three types of nitrogen were distinguished by XPS [31-33]: Py-N (398.8 eV), Pr-N (399.9 eV), and Q-N (401.0 eV). Py-N corresponds to pyridinic nitrogen. $\mathrm{Pr}-\mathrm{N}$ corresponds to pyrrolic nitrogen and to pyridinic nitrogen in association with its oxygen functionality, and mainly referred to protein nitrogen. $\mathrm{N}-\mathrm{Q}$ represents the nitrogen that substituted the carbon in the aromatic graphene structure, leading to slightly more positively charged nitrogen, resembling the quaternary nitrogen in ammonium ions. As shown in Table 5, before lime stabilization, $\mathrm{Pr}-\mathrm{N}$ accounted for $77.05 \%$ of the peak area ratio, and Q-N percentage was $22.95 \%$. In addition, there was almost no Py-N. However, the addition of lime changed the nature of the nitrogen distribution: $\mathrm{N}-\mathrm{H}$ significantly decreased, the peak area ratios of $\mathrm{N}-\mathrm{O}$ and $\mathrm{C}-\mathrm{N}$ increased, and $\mathrm{Py}-\mathrm{N}$ compounds were generated. These results were mainly due to the high-temperature and highly alkaline environment. Under these conditions, most of the $\mathrm{N}-\mathrm{H}$ reacted with the $\mathrm{O}-\mathrm{H}$ to generate $\mathrm{NH}_{3}$, and ultimately was emitted to the air. Although during the protein hydrolysis process, the chain of amino acids broke, 
a) C1s spectra
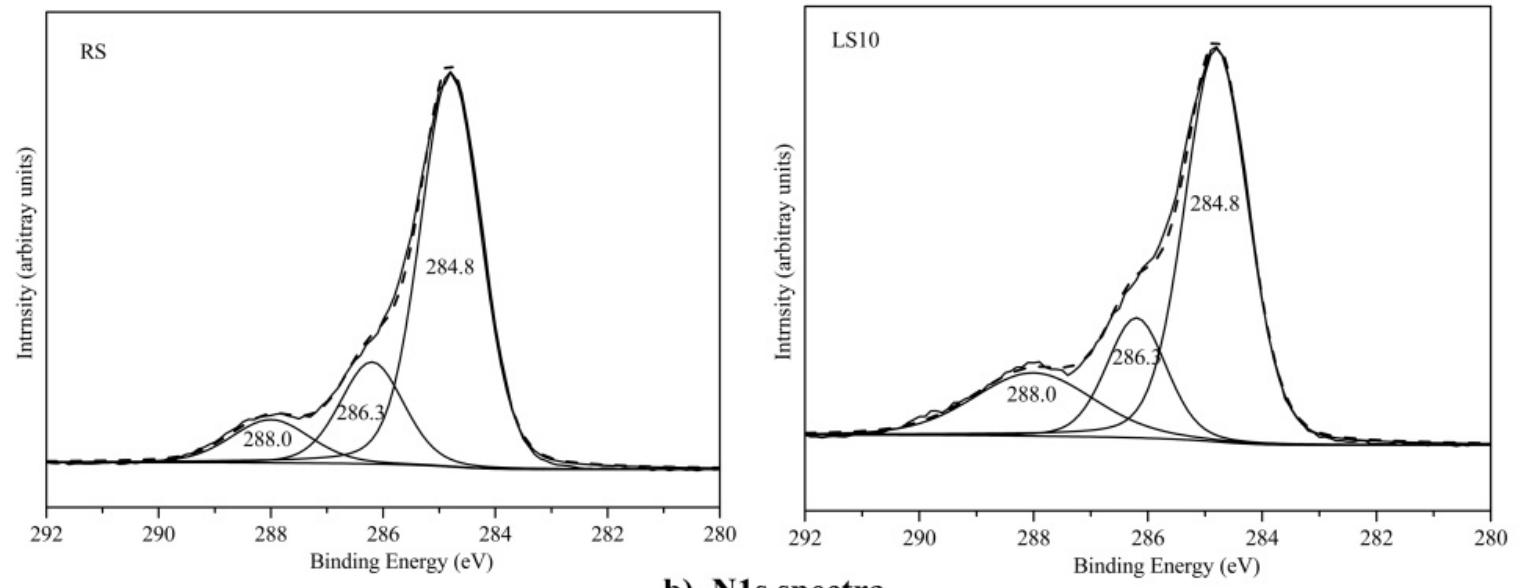

b) N1s spectra
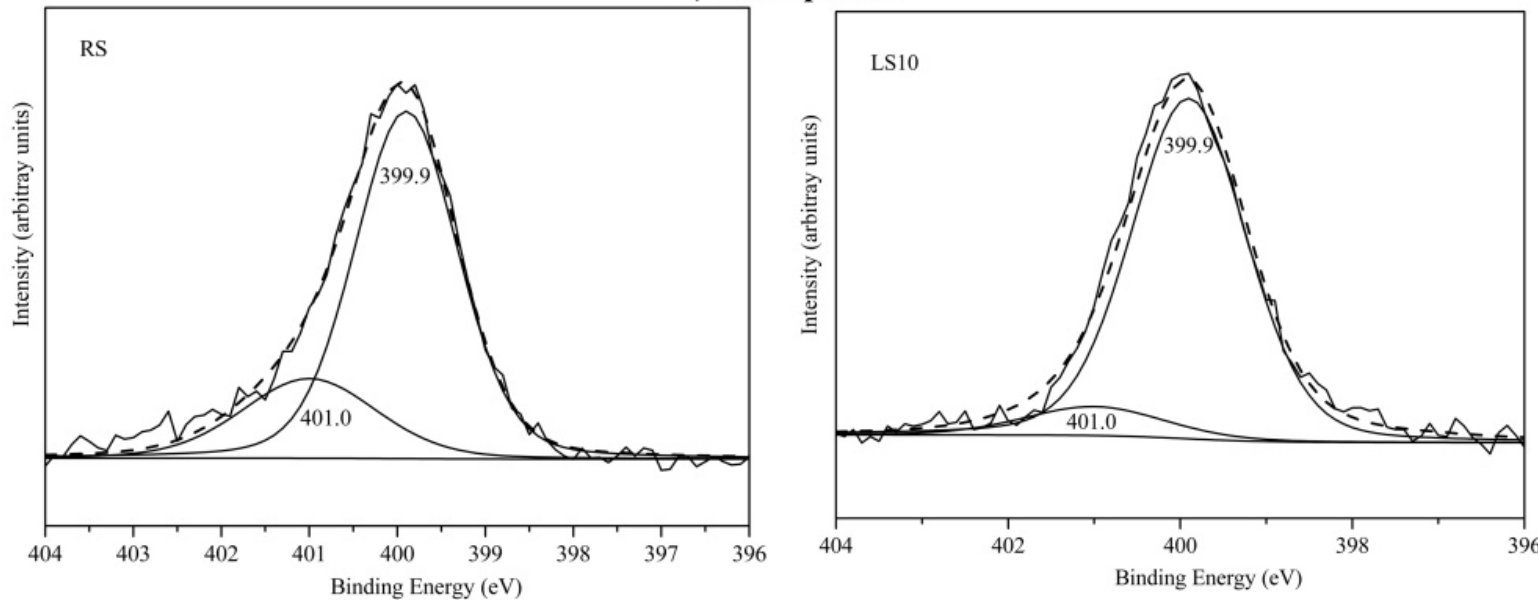

c) O1s spectra
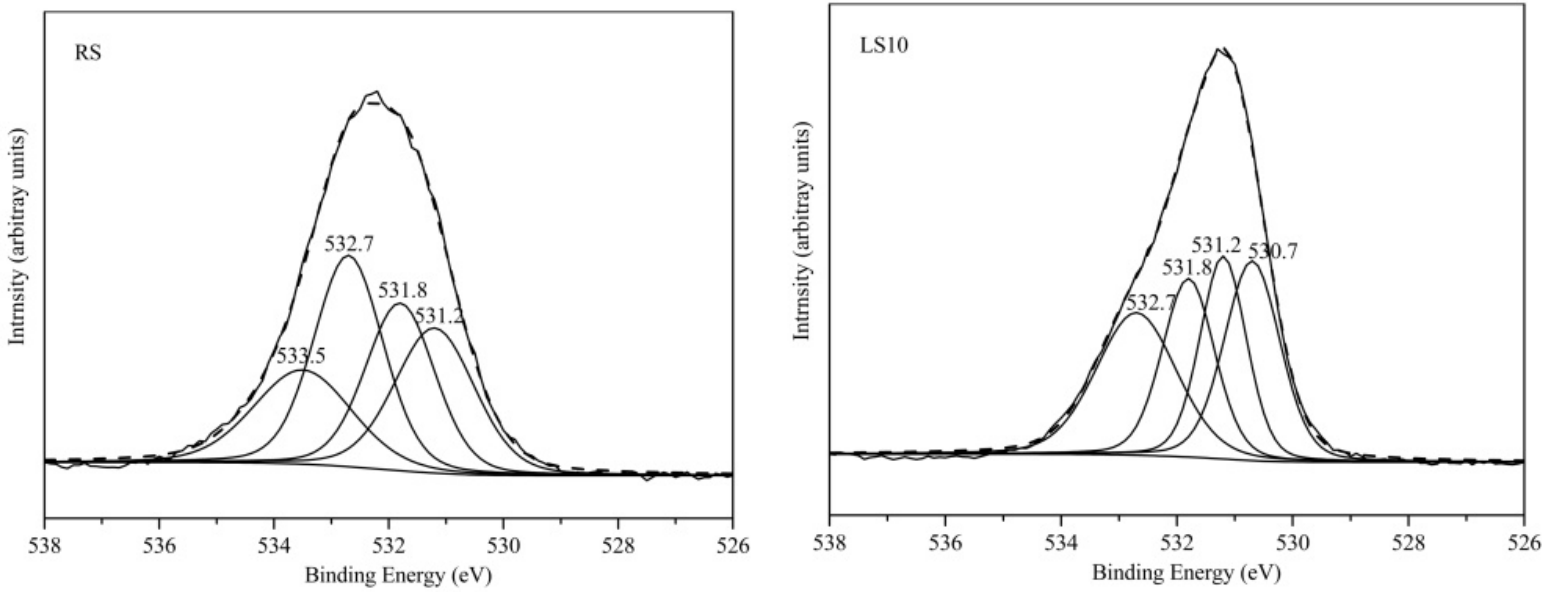

Fig. 5. XPS spectra of RS and LS10 samples after being dried for $12 \mathrm{~h}$ : a) C1s spectra, b) N1s spectra, c) O1s spectra.

$\mathrm{N}-\mathrm{O}$ and $\mathrm{C}-\mathrm{N}$ remained in the amide or amine. Moreover, the decrease in $\mathrm{N}-\mathrm{H}$ resulted in an increase in the relative ratio of $\mathrm{N}-\mathrm{O}$ and $\mathrm{C}-\mathrm{N}$. Moreover, pyridinic compounds such as the cyano aromatic compounds may have formed in two different ways: from the dehydrogenation of the amino group present in the proteins and from the addition of nitrogen radicals to the light aromatic hydrocarbons [34].

Note that all these changes could not occur in the absence of $\mathrm{CaO}$. The presence of $\mathrm{CaO}$ also meant that typical Ca $2 p$ XPS spectra could also be fitted, and these results are shown in Fig. 6.

The two peaks in the Ca $2 \mathrm{p}$ spectrum were assigned to $\mathrm{Ca} 2 \mathrm{p}_{3 / 2}$ and $\mathrm{Ca} 2 \mathrm{p}_{1 / 2}$, respectively $[35,36]$. From Fig. 6 it can be seen that the RS core level appeared at $347.50 \mathrm{eV}$ (1.45) and $351.10 \mathrm{eV}(1.88)$ binding energies, respectively, while those for LS10 appear at $346.70 \mathrm{eV}$ (1.57) and $350.30 \mathrm{eV}$ (1.52), respectively. In other words, LS had a lower core level binding energy than RS. This also suggested that the electron density around calcium atoms 
Table 5. Relative contents at different binding energy (after peak fitting).

\begin{tabular}{|c|c|c|c|c|c|c|c|}
\hline Element & Binding energy/eV & Chemical state & RS & LS05 & LS10 & LS15 & LS20 \\
\hline \multirow{3}{*}{$\mathrm{C}$} & 284.8 & $\mathrm{C}-\mathrm{C}, \mathrm{C}-\mathrm{H}$ & 70.78 & 62.95 & 63.02 & 59.16 & 64.24 \\
\hline & 286.2 & $\mathrm{C}-\mathrm{O}, \mathrm{C}-\mathrm{N}$ & 19.16 & 18.16 & 17.97 & 18.36 & 19.64 \\
\hline & 288.0 & $\mathrm{C}=\mathrm{O}, \mathrm{O}-\mathrm{C}-\mathrm{O}$ & 10.06 & 18.89 & 19.01 & 22.47 & 16.11 \\
\hline \multirow{5}{*}{$\mathrm{O}$} & 530.7 & $\mathrm{O}$ in oxides & 0.00 & 33.76 & 26.98 & 5.80 & 42.71 \\
\hline & 531.2 & $\mathrm{O}-\mathrm{H}$ & 24.68 & 18.17 & 22.71 & 19.34 & 13.16 \\
\hline & 531.8 & $\mathrm{O}=\mathrm{C}$ & 24.71 & 22.26 & 22.62 & 30.00 & 18.19 \\
\hline & 532.7 & $\mathrm{C}-\mathrm{O}-\mathrm{H}, \mathrm{C}-\mathrm{O}-\mathrm{C}, \mathrm{C}=\mathrm{O}$ & 31.01 & 25.80 & 27.69 & 44.86 & 25.94 \\
\hline & 533.5 & $-\mathrm{COOH}$ & 19.59 & 0.00 & 0.00 & 0.00 & 0.00 \\
\hline \multirow{3}{*}{$\mathrm{N}$} & 398.8 & $=\mathrm{N}-$ & 0.00 & 7.93 & 6.37 & 5.33 & 10.70 \\
\hline & 399.9 & $\mathrm{~N}-\mathrm{O}, \mathrm{C}-\mathrm{N}$ & 77.05 & 92.07 & 84.91 & 83.67 & 84.20 \\
\hline & 401.0 & $\mathrm{~N}-\mathrm{H}$ & 22.95 & 0.00 & 8.72 & 11.00 & 5.11 \\
\hline
\end{tabular}

in the surface zone was relatively higher in LS [36], which means that $\mathrm{Ca}$ probably played an adsorption-bridging role during stabilization. In particular, $\mathrm{Ca}(\mathrm{OH})_{2}$, may have reacted with amino acids to generate organic chelate and clathrate compounds, such as the synthesis of calcium glutamate [37].

\section{Discussion of Results}

\section{Effect of Sludge Properties} on Co-Processing Capacity

As stated above, the addition of lime had little effect on heavy metal, chlorine, and sulfur, but it had a marked effect on moisture content, heating value, organic forms, and chemical composition. Among the properties, chemical composition would clearly affect the coprocessing capacity.

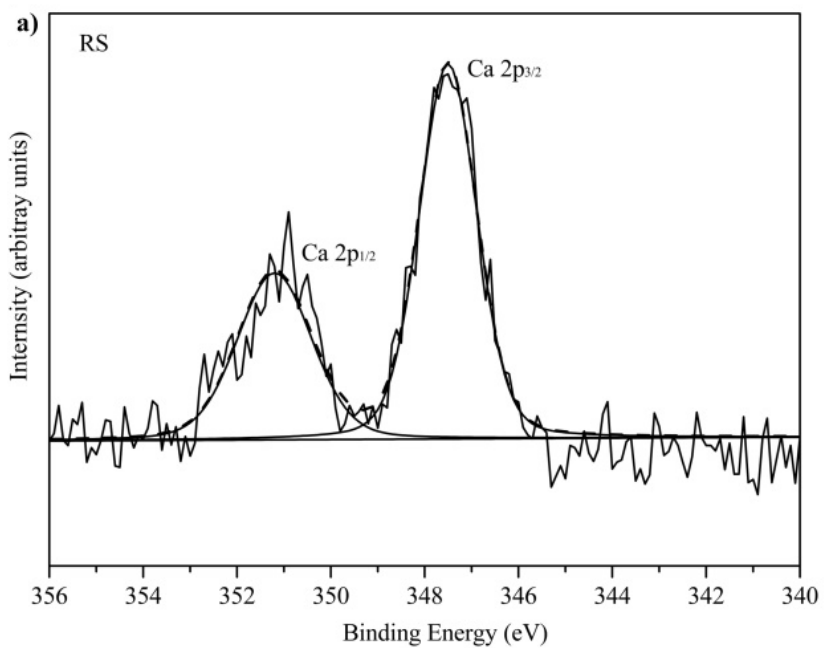

In China, the composition parameters of Chinese cement clinkers have typically been controlled at silica ratio (SM) values of around 1.70-2.70, alumina ratio (IM) values of around $0.90-1.90$, and lime saturation $(\mathrm{KH})$ values of around $0.87-0.96[38,39]$. The compositional parameters in the cement chemistry are determined by Eqs. (6-8).

$$
=\frac{\begin{array}{c}
\text { Lime saturation ratio } \mathrm{KH}= \\
\mathrm{CaO}-1.65 \mathrm{Al}_{2} \mathrm{O}_{3}-0.35 \mathrm{Fe}_{2} \mathrm{O}_{3}
\end{array}}{2.80 \mathrm{SiO}_{2}}
$$

Silica ratio $\mathrm{SM}=\frac{\mathrm{SiO}_{2}}{\mathrm{Al}_{2} \mathrm{O}_{3}+\mathrm{Fe}_{2} \mathrm{O}_{3}}$

$$
\text { Alumina ratio } \mathrm{IM}=\frac{\mathrm{Al}_{2} \mathrm{O}_{3}}{\mathrm{Fe}_{2} \mathrm{O}_{3}}
$$

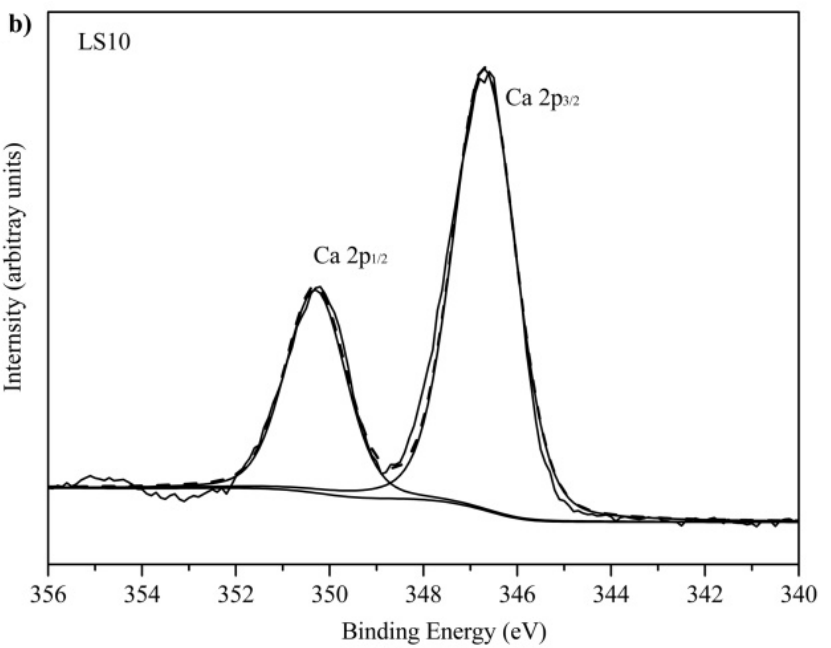

Fig. 6. Ca 2p XPS spectra of RS and LS10: a) raw sludge without $\mathrm{CaO}$ and b) raw sludge with $10 \mathrm{wt} \% \mathrm{CaO}$. 
As clearly indicated by previous results, sludge coprocessing can change the composition of the cement clinkers. Furthermore, the effect is increased with the sludge disposal amount. The maximum co-processing ratio would occur when the composition was not being controlled. Thus, by maintaining the composition at $\mathrm{KH}=0.90 \pm 0.05, \mathrm{SM}=2.50 \pm 0.10, \mathrm{IM}=1.50 \pm 0.10$, based on the data in Table 2, the maximum co-processing ratio

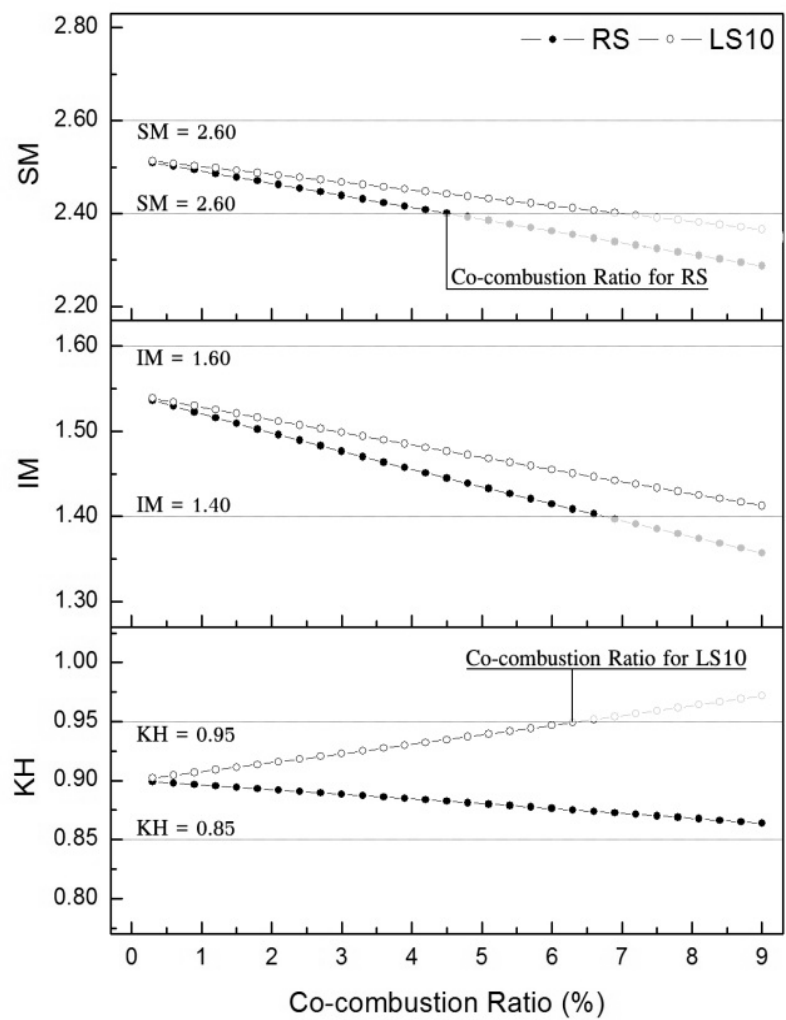

Fig. 7. Effect of the sludge co-processing ratio on clinker composition.

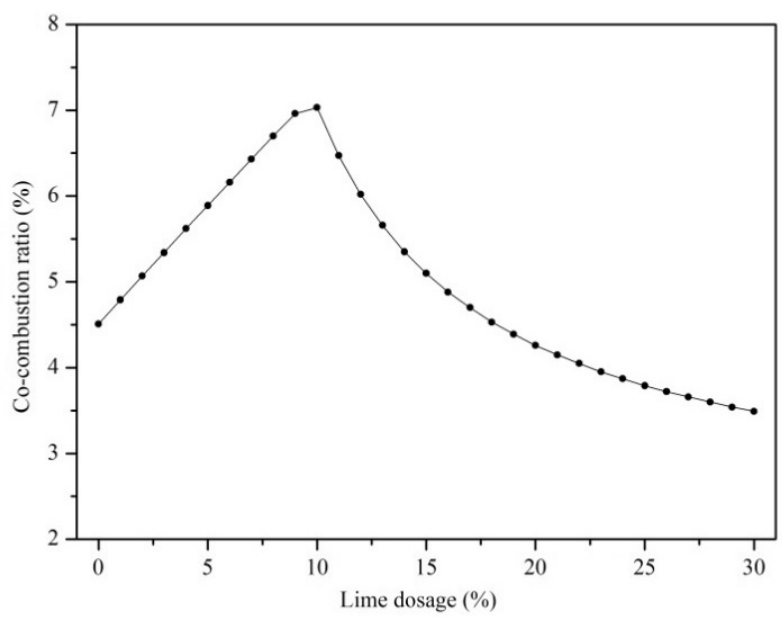

Fig. 8. Theoretical maximum co-processing ratios for different lime sludge samples. can be calculated. Using RS and LS10 as examples, the maximum co-processing ratio was determined based on the results shown in Fig. 7. As illustrated in Fig. 7, SR was the limiting parameter because of the high silt concentration in RS. However, KH was first uncontrolled after the addition of LS. Notably, the co-processing ratio increased from $4.5 \%$ to $6.5 \%$. Thus, lime stabilization was proved to enhance the sludge co-processing capacity. As previously discussed, this has been attributed to the adjustment function of lime. However, if this was the case, the co-processing ratio for LS still should not increase above $6.5 \%$. If it did, $\mathrm{KH}$ of the cement clinker would rapidly increase and the excess $\mathrm{CaO}$ would generate $\mathrm{f}-\mathrm{CaO}$, which would degrade the strength of the cement.

Some theoretical calculations also were performed to study the maximum co-processing ratios for different LS samples. It is well known that the temperature in cement kilns can reach $1,500^{\circ} \mathrm{C}$, after which all the calcium in sludge is in the form of $\mathrm{CaO}$. Thus, the theoretical calculations for the lime-drying process were simplified by adding $\mathrm{CaO}$ to the sludge ash. The relationship between lime dosage and the maximum co-processing ratios were determined. As shown in Fig. 8, the maximum co-processing ratios for RS and LS10 were $4.5 \%$ and $7.0 \%$, respectively, which were basically the same as the actual calculated values. It also could be concluded that a small amount of lime could play an important active role in improving sludge co-processing ratios. However, the lime dosage should be no higher than $10 \%$, otherwise the co-processing capacity would decrease. In short, $10 \%$ lime showed the highest ratio and is suggested as the optimum lime dosage. As stated above, the heating value of LS10 was $7,200 \mathrm{~kJ} / \mathrm{kg}(>6,250 \mathrm{~kJ} / \mathrm{kg})$, and the useful composition in ash was $44.47 \%$ ( $>40 \%)$. Thus, the properties of LS10 meet industry requirements $[13,16]$. In short, $10 \%$ is suggested as the optimum lime dosage for co-processing LS in cement kilns.

\section{Analysis of Material Flow for Co-combustion of LS in Cement Kilns}

Based on the results in section 2, Fig. 9 shows the material flow for co-processing LS in cement kilns.

For co-processing sludge in cement kilns, moisture content and chemical composition are the limiting factors. As shown in Fig. 9, dewatering sludge to a moisture content of $30 \%$ for RS and LS10 required $81.6 \mathrm{~g}$ and $64.5 \mathrm{~g}$ of water during the thermal process, respectively. In addition, LS had a higher (about 1.25) drying capacity for the same dry conditions. From Fig. 9 it also could be seen that the condensate of LS had a lower organic compound content. As discussed above, the addition of lime promoted the transformation and emission of the organic compounds. In particular, the organic sources decreased, and the organic chelate and clathrate compounds generated during the lime stabilization process had higher boiling points. Thus, there were few materials to be compensated in the condensing tower. In short, LS had a smaller condensed water yield as well as a lower pollution load, which were 


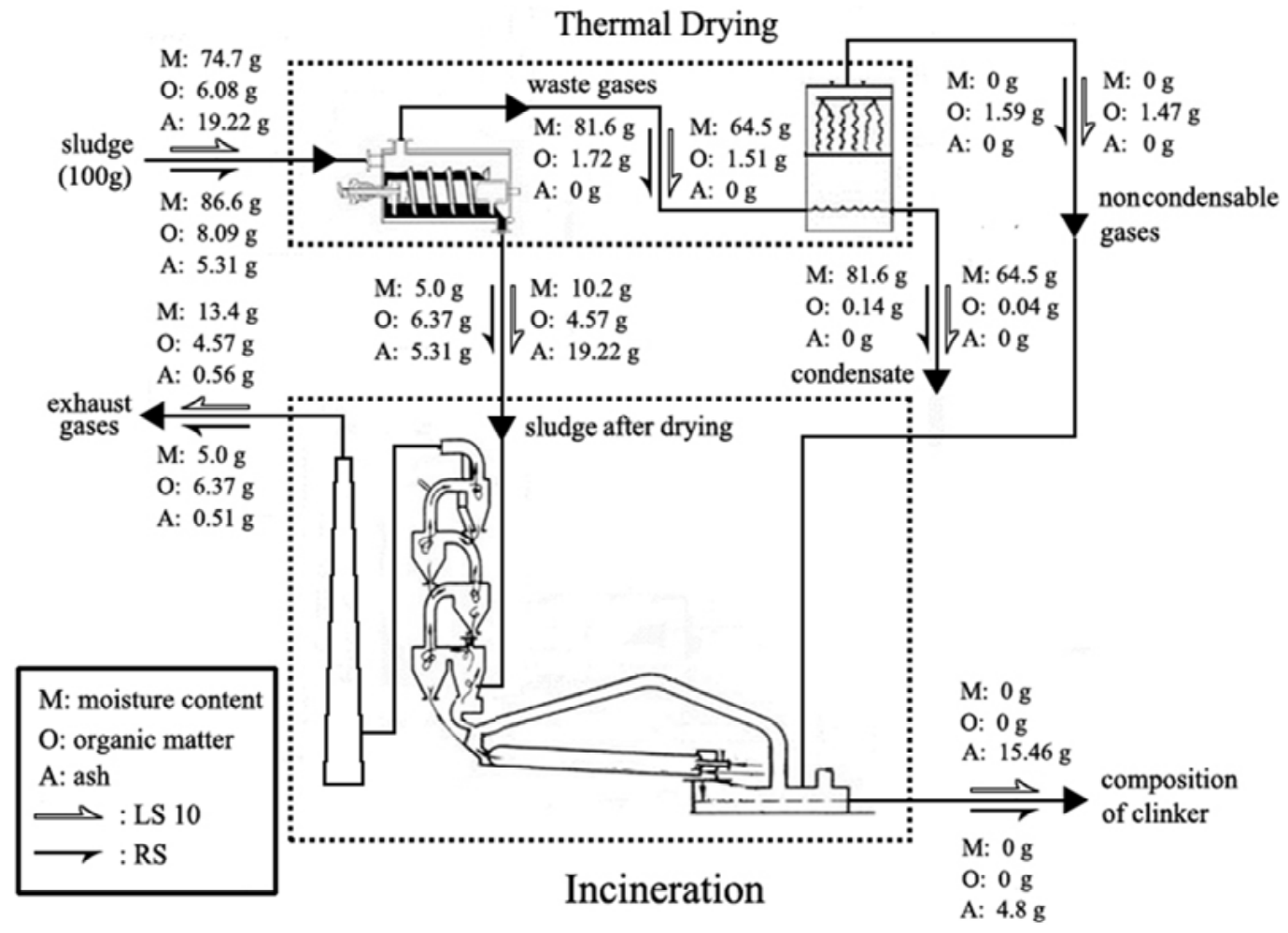

Fig. 9. Material flows for co-processing sludge in cement kiln; materials in gases were calculated by the weight difference method.

conducive for condensed water treatment and gas-phase pollution control.

As also shown in Fig. 9, compared with RS, LS had a lower amount of organic matter transformed to exhaust gases. Combined with previously shown results, LS may also have lower $\mathrm{CO}_{2}$ and $\mathrm{NOx}$ emissions. This is due to the different carbon and nitrogen contents entering the cement kiln, as well as the different nitrogen forms. After adding lime, macromolecule nitrogen-containing compounds resolve into light compounds and $\mathrm{NH}_{3}$ [34], mainly caused by the decrease in Q-N. In addition, because of nitrogenized reactions, Py-N increased. In particular, the addition of lime resulted in a decrease of $-\mathrm{NH}_{2}$-containing compounds, and an increase in acid amides $(-\mathrm{CONH})$ and nitrogen-containing heterocyclic compounds. In general, the addition of lime caused Q-N to decrease, and $\mathrm{Pr}-\mathrm{N}$ and $\mathrm{Py}-\mathrm{N}$ to increase. Furthermore, in the study by Kambara [40], it was believed that the dominant factors controlling $\mathrm{NO}_{\mathrm{x}}$ emissions were the amount of volatile nitrogen and the $\left[\mathrm{NH}_{3}\right] /[\mathrm{HCN}]$ ratio. These $\mathrm{NH}_{3}$ yields can be replaced by the weight percentage of Q-N. HCN yields are the sum of the weight percentages of $\mathrm{Pr}-\mathrm{N}$ and $\mathrm{Py}-\mathrm{N}$. Thus, adding lime can lead to a lower $\left[\mathrm{NH}_{3}\right] /[\mathrm{HCN}]$ ratio in sludge and co-processing LS in cement kilns may result in lower $\mathrm{NO}_{\mathrm{x}}$ emissions than with $\mathrm{RS}$.

\section{Conclusions}

In this study, the effect of lime on moisture content, chemical composition, organic matter, and heating value of sludge was investigated. Based on the results, influences on the co-processing ratio and the material flow during co-processing sludge in cement kilns were also discussed. The main conclusions are as follows.

The addition of lime significantly reduced the moisture content and water-solid bond strength in sludge samples. The moisture content was less than $60 \%$ and LHV was greater than $1,900 \mathrm{~kJ} / \mathrm{kg}$ for all LS samples dried for seven days.

In contrast to RS, LS had a composition more similar to cement raw material. Adding LS changed the relative content of $\mathrm{SiO}_{2}, \mathrm{CaO}, \mathrm{Fe}_{2} \mathrm{O}_{3}$, and $\mathrm{Al}_{2} \mathrm{O}_{3}$ in cement raw meal, which improved the sludge co-processing capacity in the cement kiln. Heavy metal, chlorine, and sulfur content of LS are on low level and could completely meet the relation requirement.

Different lime dosages to the sludge had different effects on the maximum sludge co-processing ratio. For lime dosage between $0 \%$ and $10 \%, \mathrm{CaO}$ played a role in adjusting the chemical composition, and a higher sludge co-processing capacity could be achieved. However, when the lime dosage was above $10 \%$, a negative effect of the microelements dominated and the maximum sludge co-processing ratio decreased. Lime dosage of $10 \%$ is suggested as being the optimum dosage for co-processing LS in cement kilns, and the sludge addition ratio should not be greater than $6.5 \%$.

Adding lime enhanced gas pollution control during co-processing. The aromatic compounds are decreased, and thus positively affect the environment rotation. The addition of lime also promoted the decomposition and 
transformation of $\mathrm{Q}-\mathrm{N}$ and the generation of $\mathrm{Py}-\mathrm{N}$. Compared with RS, co-processing LS may also achieve lower $\mathrm{NO}_{\mathrm{x}}$ emissions.

\section{Acknowledgements}

This study was supported by the National Major Science and Technology Project of Water Pollution Control and Management, China (Grant No. 2010ZX07319-00102).

\section{References}

1. MOHURD (Ministry of housing and urban-rural development of the People's Republic of China). http:// wwwmohurdgoven/zcfg/jsbwj_0/jsbwjcw/201408/ t20140805 218642html.

2. National Bureau of Statistics of the People's Republic of China. China Statistics book 2011. China Statistics Press: Beijing, 2012.

3. YIN J., TAN X.J. Sewage sludge treatment theory and technology. Beijing, 2005.

4. YING M.J., ZHAO Z.F., CUI X.L., ZHAO Y., CHEN X.H., ZHANG J. Application of Sludge Lime Drying Process in Xiaohongmen WWTP in Beijing. China water \& wastewater. 27 (6), 75, 2011 [In Chinese, English Summary].

5. ZHANG S.Y., ZHANG H., GAN Y.P., ZHAO S., ZHOU J., WEI, W., CHEN Z.T. Application Research on Sludge Lime Drying Process for Municipal Wastewater Treatment Plant. Water Purification Technology. 28 (1), 75, 2009 [In Chinese, English Summary].

6. WANG Z.J., LI Q.S., GUO H.C., XU Y.L., YU X.J. Study on key infulence factors for sludge lime drying. China water \& wastewater. 30 (5), 85, 2014 [In Chinese, English Summary]

7. LIU X., SHI J., ZHAO Y., LI Z.F., ZHANG J. Experimental research on lime drying process of mechanical dewatered sludge from a wastewater treatment plant in Beijing. Procedia. Environ. Sci. 16, 335, 2012.

8. KELESSIDIS A., STASINAKIS A.S. Comparative study of the methods used for treatment and final disposal of sewage sludge in European countries. Waste manage. 32 (6), 1186, 2012.

9. Standardization adminstration of the People's Republic of China. Disposal of sludge from municipal wastewater treatment plant - Quanlity of sludge for co-landfilling. In Beijing, 2009.

10. WERTHER J., OGADA T. Sewage sludge combustion. Prog. Energ. Combust. 25 (1), 55, 1999.

11. LI X., TAKAOKA M., ZHU F., WANG J., OSHITA K., MIZUNO T. Environmental and economic assessment of municipal sewage sludge management - a case study in Beijing, China. Water science and technology : a journal of the International Association on Water Pollution Research. 67 (7), 1465, 2013.

12. KONG X.J., WEI L.L., XUE C.H., REN H.J. Current situation of the municipal sewage sludge treatment by combined process of cement kiln incineration and its policy demand analysis. Water and wastewate engineering. 38 (6), 22, 2012 [In Chinese, English Summary].

13. HASANBEIGI A., LU H., WILliAMS C., PRICE L. International Best Practices for Pre-Processing and Co-
Processing Municipal Solid Waste and Sewage Sludge in the Cement Industry Berkeley Lab, 2012.

14. WZOREK, M. Characterisation of the properties of alternative fuels containing sewage sludge. Fuel. Process. Technol. 104, 80, 2012.

15. Cement Sustainability Initiative CSI. Guidelines for the Selection and Raw Materials in the Cement Manufacturing Process, WBCSD, 2005.

16. RODRÍGUEZ N.H., MARTÍNEZ-RAMÍREZ S., BLANCOVARELA M.T., DONATELLO S., GUILLEM M., PUIG J., FOS C., LARROTCHA E., FLORES J. The effect of using thermally dried sewage sludge as an alternative fuel on Portland cement clinker production. J. Clean. Prod. 52, 94, 2013.

17. HONG J., LI X. Environmental assessment of sewage sludge as secondary raw material in cement production-a case study in China. Waste. manage. 31 (6), 1364, 2011.

18. HE P.J., LÜ F., ZHANG H., SHAO L.M., LEE D.J. Sewage sludge in China: challenges toward a sustainable future. Water Practice and Technology. 2 (4), 1, 2007.

19. JIN L., ZHANG G., TIAN H. Current state of sewage treatment in China. Water research. 66C, 85, 2014.

20. CHEN G.W., HUNG W.T., CHANG I.L., LEE S.F., LEE D.J. Continuous classification of moisture content in waste activated sludges. J. Environ. Eng-Asce. 123 (3), 253, 1997.

21. MOHURD (Ministry of housing and urban-rural development of the People's Republic of China). Code for design of sludge co-processing in cement kiln. China Plan Publishing Company. Beijing, 2005 [In Chinese].

22. STASTA P., BORAN J., BEBAR L., STEHLIK P., ORAL J. Thermal processing of sewage sludge. Appl. Therm. Eng. 26 (13), 1420, 2006.

23. XU W., XU J.C, LIU J., LI H.X., CAO B., HUANG X.F., LI G.M. The utilization of lime-dried sludge as resource for producing cement. J. Clean. Prod. 83, 286, 2014.

24. MOHURD (Ministry of housing and urban-rural development of the People's Republic of China). Code for design of sludge $c o=$ processing in cement kiln. China planning press: Beijing, 2012 [In Chinese].

25. HASANBEIGI A., LU H., WILLIAMS C., PRICE L. International Best Practices for Pre-Processing and CoProcessing Municipal Solid Waste and Sewage Sludge in the Cement Industry. Berkeley Lab, 2012 [In Chinese].

26. AQSIQ (General Administration of Quality Supervision, Inspection and Quarantine of the People's Republic of China). Common Portland Cement. Standards press of China: Beijing, 2007 [In Chinese].

27. WONG J.W.C., SELVAM A. Reduction of indicator and pathogenic microorganisms in pig manure through fly ash and lime addition during alkaline stabilization. J. Hazard. Mater. 169 (1-3), 882, 2009.

28. LU C., TONGBIN C., DING G., JUN Y., JUN C. Investigation on calorific value of sewage sludges in large and middle cities of China. China water \& wastewater. $\mathbf{2 6}$ (15), 106-108, 2010 [In Chinese, English Summary].

29. SUN X.F., WANG S.G., CHENG W., FAN M., TIAN B.H., GAO B.Y., LI X. M. Enhancement of acidic dye biosorption capacity on polyethylenimine. grafted anaerobic granular sludge. J. Hazard. Mater. 189 (1-2), 27, 2011.

30. SU W., TANG B., FU F., HUANG S., ZHAO S., BIN L., DING J., CHEN C. A new insight into resource recovery of excess sewage sludge: feasibility of extracting mixed amino acids as an environment-friendly corrosion inhibitor for industrial pickling. J. Hazard. Mater. 279, 38, 2014.

31. LIU H., LUO G.Q., HU H.Y., ZHANG Q., YANG J.K., YAO H. Emission characteristics of nitrogen- and sulfur- 
containing odorous compounds during different sewage sludge chemical conditioning processes. J. Hazard. Mater. 235-236, 298, 2012.

32. LIU W., XU J.C. LIU J., CAO H.H., HUANG X.F., LI G.M. Characteristics of ammonia emission during thermal drying of lime sludge for co-combustion in cement kilns. Environ. Technol. 36 (2), 226, 2015.

33. KAPTEIJN F., MOULIJN J.A., MATZNER S., BOEHM H.P. The development of nitrogen functionality in model chars during gasification in $\mathrm{CO}_{2}$ and $\mathrm{O}_{2}$. Carbon. 37, 1143, 1999.

34. FULLANA A., CONESA J.A., FONT R., MARTÍNGULLÓN I. Pyrolysis of sewage sludge: nitrogenated compounds and pretreatment effects. J Anal Appl Pyrol. 6869, 561, 2003.

35. FRATEUR I., CARNOT A., ZANNA S., MARCUS P. Role of $\mathrm{pH}$ and calcium ions in the adsorption of an alkyl $\mathrm{N}$-aminodimethylphosphonate on steel: An XPS study. Appl. Surf. Sci. 252 (8), 2757, 2006.
36. NI M., RATNER B.D. Differentiation of Calcium Carbonate Polymorphs by Surface Analysis Techniques - An XPS and TOF-SIMS study. Surf. Interface. Anal. 40 (10), 1356, 2008.

37. WEI L.Y., QIAN J.Q., PENG W., WEI S.L., DING Y.G. Studies on Synthetic Conditions of Calcium-Glutamate Chelate. Amino Acids \& Biotic Resources. 31, 43, 2009 [In Chinese, English Summary].

38. LIN K.L., LIN D.F., LUO H.L. Influence of phosphate of the waste sludge on the hydration characteristics of eco-cement. J. Hazard. Mater. 168 (2-3), 1105, 2009.

39. LIN Y., ZHOU S., LI F., LIN Y. Utilization of municipal sewage sludge as additives for the production of eco-cement. J. Hazard. Mater. 213-214, 457, 2012.

40. KAMBARA S., TAKARADA T., TOYOSHIMA M., KATO K. Relation Between Functional Forms Of Coal Nitrogen And Nox Emissions From Pulverized Coal Combustion. Fuel. 74 (9), 1247, 1995. 